\title{
Petchoa in vitro culture
}

Alatortseva T. A.

Saratov State University, Saratov, Russia

E-mail: alatortsevata@mail.ru

Key message. The possibility of Petchoa hybrid Beautical Caramel Yellow in vitro propagation was investigated. The optimal concentration of phytohormones for regeneration has been established.

Keywords: petchoa, leaf explants, in vitro, regeneration

In decorative floriculture, along with Petunia and Calibrachoa, their intergeneric hybrid $-\times$ Petchoa G. Boker \& J.M.H. (Petunia Juss. $\times$ Calibrachoa Cerv. Ex La Llave \& Lex) is becoming popular [1]. Petchoa combines the best qualities of parents: large flowers and fast growth from Petunia, unique flowers color, small leaves without stickiness like Calibrachoa. Commercial and scientific interests in the intergeneric hybrid require its mass reproduction. Petchoa is an allopolyploid with the number of chromosomes $3 \mathrm{n}=25$. One chromosome set was obtained from Petunia, $2 \mathrm{n}=14$, and two sets from Caliberachoa, $4 \mathrm{n}=36$ [2]. Genome imbalance and cytoplasmic male sterility inherited from Calibrachoa [3] prevent seed propagation of the hybrid. The method of clonal micropropagation allows to overcome difficulties. The purpose of the experiment is to evaluate the regeneration potential of petchoa during in vitro cultivation. Fragments of Petchoa hybrid Beautical Caramel Yellow leaves were explanted. The nutrient medium included MS mineral salts, vitamins, sucrose, and IAA and BAP in various combinations. There were 6 variants. Positive reaction of explants to cultivation conditions was revealed. There were: callusogenesis (morphogenic and non-morphogenic), hemmogenesis and regenerant development. The intensity and type of morphogenetic processes depended on the concentrations of IAA and BAP.The maximum amount of regenerants is observed on nutrient medium with IAA $-2.0 \mathrm{mg} / \mathrm{l}$ and BAP $-4 \mathrm{mg} / \mathrm{l}$. The results suggest that Petchoa Hybrid Beautical Caramel Yellow can be a promising object for in vitro propagation.

\section{Культура in vitro петхоа \\ Алаториева Т.А.}

ФГБОУ ВО «Саратовский национальный исследовательский государственный университет имени Н.Г. Чернышевского», Саратов, Россия

Аннотация. Исследована возможность размножения Petchoa hybrid Beautical Caramel Yellow культуре in vitro. Установлена оптимальная для регенерации концентрация фитогормонов.

Ключевые слова: петхоа, листовые экспланты, in vitro, регенерация

В декоративном цветоводстве, наряду с петунией и калибрахоа, становится популярным их межродовой гибрид Петхоа $\times$ Petchoa G. Boker \& J.M.H. (Petunia Juss. $\times$ Calibrachoa Cerv. ex La Llave \& Lex) [1]. В петхоа сочетаются лучшие качества родителей: крупные цветки и быстрый рост от петунии, уникальная окраска цветков, мелкие листья без липкости как у калибрахоа. Коммерческий и научные интересы к межродовому гибриду требуют его массового воспроизводства. Петхоа - аллополиплоид с числом хромосом $3 \mathrm{n}=25$. Один хромосомный набор получен от петунии, $2 \mathrm{n}=14$ и два набора - от калибрахоа, $4 \mathrm{n}=36$ [2]. Несбалансированность генома и цитоплазматическая мужская стерильность, унаследованная от калибрахоа [3], препятствуют семенному размножению гибрида. Преодолеть трудности позволяет метод клонального микроразмножения. Цель настоящей работы - оценить регенерационный потенциал петхоа при культивировании in vitro. Эксплантировали фрагменты листьев Petchoa hybrid Beautical Caramel Yellow. Питательная среда включала минеральные соли MS, витамины, сахарозу, а также ИУК и БАП в различных комбинациях. Всего 6 вариантов. Выявлена позитивная реакция эксплантов на условия культивирования. Имели место: каллусогенез (морфогенный и неморфогенный), геммогенез и развитие регенерантов. Интенсивность и типы морфогенетических процессов зависели от концентраций ИУК и БАП. Максимальное количество регенерантов отмечено на питательной среде с ИУК - 2,0 мг/л и БАП - 4 мг/л. Результаты позволяют заключить, что Petchoa hybrid Beautical Caramel Yellow может быть перспективным объектом для воспроизводства в условиях in vitro.

1. Shaw, J.M.H. A new hybrid genus for Calibrachoa $\times$ Petunia (Solanaceae) / J.M.H. Shaw // Hanburyana. - 2007. - Vol. 2. - P. 50-51.

2. Jędrzejuka, A. Characterization of interspecific hybrids of Petunia and Calibrachoa by multiplex PCR, DNA content, and chromosome number / A. Jędrzejuka, L. Meyerb, M. Serek // J. Hortic. Sci. Biotech. - 2017. - Vol. 92, -_No.5. - P. $493-501$.

3. Colombo, N. A novel source of cytoplasmic male sterility in Calibrachoa pubescens / N.Colombo, A.Coviella, J. C Hagiwara // Revista Brasileira de Horticultura Ornamental. 2017. - Vol. 23. - No. 3. - P. 311-318. 